\title{
PENGARUH KOMPENSASI DAN MOTIVASI KERJA TERHADAP KINERJA KARYAWAN PEMANEN DI PTPN III KEBUN SEI SILAU AFDELING III KABUPATEN ASAHAN PROVINSI SUMATERA UTARA
}

\author{
M. Afdal Zikri ${ }^{1}$, Yelfiarita ${ }^{2}$, Darnetti $^{2}$ \\ ${ }^{1}$ Mahasiswa Politeknik Pertanian Negeri Payakumbuh \\ ${ }^{2}$ Dosen Pembimbing Mahasiswa Politeknik Pertanian Negeri Payakumbuh \\ Email:yelfiarita@gmail.com
}

\begin{abstract}
The research was conducted in Afdeling 3 Sei Silau garden with a land area of 683,26 ha to harvest employees. This study aims to analyze the effect of compensation and work motivation on employee performance simultaneously and analyze the effect of compensation and work motivation on employee performance partially in PTPN III Sei Silau garden. The study was conducted on 20 February to 19 April. The data used in this research are primary data and secondary data. The sample in this study amounted to 24 who did the filling questionnaire. Questionnaire data using Likert scale. The data obtained were processed using quantitative descriptive method. Based on the results of data analysis and hypothesis testing has been done, it can be concluded that overall, there is a significant influence between the variable compensation (XI) and work motivation (X2) on employee performance $(Y)$ with significance value $f 0.000<\alpha=0.005$ which has an adjusted value of $R$ Square 0.868, meaning compensation (X1) and work motivation (X2) affect employee performance of $86.8 \%$ and the remaining $13.2 \%$ influenced by other variables not discussed in this study. Partially, there is a significant influence between the compensation variable (X1) on employee performance $(Y)$ with the value of beta coefficient 0.951 with significance t $0.000<\alpha=0.005$ and there is a significant influence between work motivation variable (X2) on employee performance $(Y)$ with beta coefficient value 0.257 with significance t $0.031<\alpha=0.005$.
\end{abstract}

Keywords: Compensation, Work motivation, Performance

\begin{abstract}
ABSTRAK
Karyawan pemanen merupakan sumber daya manusia yang dimiliki oleh PT. Perkebunan Nusantara III yang penting dan harus diperhatikan karena berhubungan dengan kuantitas dan kualitas produksi buah kelapa sawit. Penelitian dilakukan di Afdeling 3 kebun Sei Silau terhadap karyawan pemanen yang berjumlah 24 orang. Afdeling 3 merupakan bagian dari PT. Perkebunan Nusantara III Kebun Sei Silau dengan luas 683.26 ha. Penelitian ini bertujuan untuk menganalisis pengaruh kompensasi dan motivasi kerja terhadap kinerja karyawan secara simultan dan menganalisis pengaruh kompensasi dan motivasi kerja terhadap kinerja karyawan secara parsial di PTPN III kebun Sei Silau. Penelitian dilakukan pada 20 Februari hingga 19 April. Data yang digunakan dalam penelitian ini yaitu data primer dan data sekunder. Responden dalam penelitian ini berjumlah 24 yang melakukan pengisian kuesioner. Data kuesioner menggunakan skala Likert. Data yang didapatkan diolah menggunakan metode deskriptif kuantitatif. Berdasarkan hasil analisis data dan pengujian hipotesis yang telah dilakukan, maka dapat diambil kesimpulan yaitu secara keseluruhan, terdapat pengaruh yang signifikan antara variabel kompensasi (X1) dan motivasi kerja (X2) terhadap kinerja karyawan (Y) dengan nilai signifikansi f $0.000<$ $\alpha=0.005$ yang mempunyai nilai adjusted R Square 0.868 , artinya kompensasi (X1) dan motivasi kerja (X2) mempengaruhi kinerja karyawan sebesar $86.8 \%$ dan sisanya $13.2 \%$ dipengaruhi oleh variabel lain yang tidak dibahas dalam penelitian ini. Secara parsial, terdapat pengaruh yang signifikan antara variabel kompensasi (X1) terhadap kinerja karyawan (Y) dengan nilai koefisien beta 0.951 dengan signifikansi t $0.000<\alpha=0.005$ dan terdapat pengaruh yang signifikan antara variabel motivasi kerja (X2) terhadap kinerja karyawan (Y) dengan nilai koefisien beta 0.257 dengan signifikansi t $0.031<\alpha=0.005$. Kata kunci: Kompensasi, Motivasi kerja, Kinerja karyawan
\end{abstract}

\section{PENDAHULUAN}

Tingkat profesionalitas karyawan dalam bekerja diukur dari kinerja mereka. Terciptanya kinerja karyawan yang tinggi tentu ada faktor yang mempengaruhinya, faktor-faktor tersebut yaitu 
kondisi sarana dan prasarana, suasana lingkungan kerja, pendidikan, pelatihan, adanya motivasi kerja, dan pemberian kompensasi. Pada penelitian ini diambil dua faktor yang mempengaruhi kinerja yaitu motivasi kerja dan pemberian kompensasi. Pengambilan dua faktor ini dengan pertimbangan pengukuran faktor kompensasi dan motivasi kerja dapat dilakukan dalam jangka waktu pendek sehingga dapat diambil datanya dengan keterbatasan waktu dalam penelitian.

Kompensasi merupakan semua pendapatan yang diterima oleh karyawan dalam bentuk uang, barang langsung dan tidak langsung sebagai imbalan atas jasa yang diberikan terhadap perusahaan. Kompensasi yang diberikan kepada karyawan terdiri dari upah, insentif, tunjangan, dan fasilitas. Pemberian kompensasi merupakan suatu usaha yang dilakukan oleh perusahaan terhadap karyawannya untuk menghargai prestasi karyawan, menjamin keadilan gaji karyawan, mempertahankan karyawan atau mengurangi turnover karyawan, memperoleh karyawan yang bermutu, pengendalian biaya, dan memenuhi peraturan-peraturan (Hasibuan dan Malayu, 2014).

Motivasi kerja adalah kemauan yang timbul dari diri maupun dari luar karyawan yang akan memberikan dorongan atau energi yang menggerakkan perilaku ke arah mencapai kebutuhan yang bisa memberi kepuasan berhubungan dengan lingkungan kerja. Pemberian motivasi kerja terhadap karyawan secara tepat akan menimbulkan semangat, gairah, dan keikhlasan kerja dalam diri. Meningkatnya motivasi kerja karyawan akan menghasilkan pekerjaan yang lebih baik sehingga dapat meningkatkan produktifitas kerja, sedangkan seseorang yang mempunyai motivasi kerja yang rendah akan bekerja dengan seenaknya dan tidak berusaha untuk mendapatkan hasil yang maksimal. Faktorfaktor yang mempengaruhi motivasi kerja diantaranya pencapaian penyelesaian tugas yang berhasil berdasarkan pada tujuan dan sasaran, penghargaan terhadap pencapaian tugas dan sasaran yang telah ditetapkan, sifat dan ruang lingkup pekerjaan itu sendiri, adanya peningkatan, adanya tanggung jawab, adanya administrasi dan kebijaksanaan pemerintah, supervisi, kondisi kerja, gaji, status, dan keamanan kerja (Sinungan, 2003)

Kompensasi dan motivasi kerja akan mempengaruhi kinerja karyawan. Kinerja karyawan yang baik sangat diperlukan dalam pencapaian tujuan organisasi. Kinerja karyawan merupakan hasil kerja dari karyawan dalam jangka waktu tertentu yang dibandingkan dengan kemungkinan yang akan dicapai perusahaan seperti target, standar atau sasaran yang telah disepakati. Pencapaian kinerja perusahaan sangat dipengaruhi oleh kinerja karyawan perusahaan itu sendiri. Keberhasilan perusahaan dipengaruhi oleh efektifitas kinerja karyawan yang baik. Perusahaan diharuskan untuk bisa mengelola sumber daya manusianya dengan baik agar tercapai tujuan yang diharapkan. Kinerja karyawan dipengaruhi berbagai faktor diantaranya adalah kompensasi yang diterima karyawan dan motivasi kerja karyawan.

PT. Perkebunan Nusantara III salah satu perusahaan yang bergerak dalam bidang produksi yaitu komoditi kelapa sawit, selain kelapa sawit terdapat juga komoditi karet. Penelitian dilakukan pada pemanen kelapa sawit Afdeling 3 yang berjumlah 24 orang yang dibawahi oleh 2 orang Mandor panen dengan masing-masing 12 orang karyawan pemanen. Salah satu perusahaan yang memberikan kompensasi dan motivasi kerja untuk mendapatkan dan mempertahankan kinerja karyawan adalah PT. Perkebunan Nusantara III kebun Sei Silau.

PT. Perkebunan Nusantara III memberikan kompensasi kepada karyawannya antara lain kompensasi finansial (upah/gaji, bonus, tunjangan ,dan asuransi keselamatan) dan kompensasi non finansial (promosi dan tunjangan). Motivasi kerja karyawan di PT. Perkebunan Nusantara III diantaranya adanya jaminan keselamatan kerja, pihak perusahaan peduli terhadap prestasi kerja yang dicapai, dan pimpinan memberikan dorongan agar bekerja lebih baik.

Atas dasar pentingnya kompensasi dan motivasi kerja untuk meningkatkan kinerja karyawan, maka penulis tertarik melakukan penelitian dengan judul "Pengaruh Kompensasi dan Motivasi Kerja terhadap Kinerja Karyawan Pemanen di PT. Perkebunan Nusantara III Kebun Sei Silau Afdeling 3 Kabupaten Asahan Provinsi Sumatera Utara".

\section{METODE PENELITIAN}

Penelitian dilakukan di PTPN III kebun Sei Silau, Kabupaten Asahan, Sumatera Utara pada tanggal 20 Februari sampai 19 April 2018. Penelitian dilaksanakan dengan cara mengumpulkan datadata yang berkaitan dengan kompensasi, motivasi kerja, dan kinerja karyawan pemanen di Afdeling 
III kebun Sei Silau. Data yang diambil yaitu data primer dan data sekunder. Data primer dalam penelitian yaitu data kuesioner yang diisi oleh karyawan pemanen mengenai kompensasi dan motivasi kerja, dan data kuesioner kinerja karyawan yang diisi oleh Mandor panen. Data sekunder yaitu data mengenai profil perusahaan PTPN III, golongan, gaji, tunjangan karyawan.

Pelaksanaan penelitian ini dimulai dari pembuatan kuesioner mengenai kompensasi, motivasi kerja, dan kinerja. Setelah data terkumpulkan, lalu dilanjutkan pengolahan data secara statistika. Metode pengumpulan data dengan cara pengisian kuesioner mengenai variabel kompensasi, motivasi kerja, dan kinerja. Kuesioner diisi oleh seluruh karyawan pemanen di Afdeling III kebun Sei Silau yang berjumlah 24 orang mengenai variabel kompensasi dan motivasi kerja. Kuesioner mengenai variabel kinerja diisi oleh Mandor panen. Data yang telah dikumpulkan kemudian ditranformasikan dengan metode skala Likert, selanjutnya diolah secara statistik dengan menggunakan software SPSS versi 20 untuk pengambilan kesimpulan mengenai pengaruh kompensasi dan motivasi kerja terhadap kinerja karyawan pemanen di Afdeling 3 kebun Sei Silau.

Metode analisis menggunakan analisis deskriptif kualitatif dan deskriptif kuantitatif. Deskriptif kualitatif yaitu persepsi, pendapat, dan kepercayaan orang tidak dapat diukur dengan angka, serta keadaan perusahaan dan proses pemberian kompensasi dan motivasi kerja. Metode analisis deskriptif kuantitatif dilakukan menggunakan software SPSS versi 20, analisis yang dilakukan antara lain uji uji reliabilitas, uji validitas, uji asumsi klasik (normalitas, uji linearitas, uji multikolinearitas, uji heteroskedastisitas), kemudian uji regresi linear berganda dan uji hipotesis apabila uji prasyarat yang dilakukan telah terpenuhi.

\section{HASIL DAN PEMBAHASAN}

\section{Karakteristik Responden}

Penelitian mengenai pengaruh kompensasi dan motivasi kerja terhadap kinerja karyawan pemanen di PTPN III kebun Sei Silau. Hal ini bertujuan untuk mengetahui pengaruh kompensasi dan motivasi kerja terhadap kinerja karyawan pemanen secara simultan dan parsial. Responden sebagai sampel dalam penelitian ini menggunakan seluruh populasi karyawan pemanen di Afdeling 3 yang berjumlah 24 orang. Karakteristik responden berguna untuk menggambarkan identitas dari sampel yang digunakan dalam penelitian ini. Karakteristik responden tersebut dapat dikelompokkan berdasarkan usia, status, golongan, pendidikan, dan masa kerja. Karakteristik responden tersebut disajikan pada tabel sebagai berikut:

1. Responden berdasarkan Usia

Tabel 1. Karakteristik responden berdasarkan usia

\begin{tabular}{ccc}
\hline Umur & Jumlah (orang) & Persentase (\%) \\
\hline $30-35$ & 6 & 25.0 \\
$36-40$ & 17 & 70.8 \\
$>40$ & 1 & 4.2 \\
\hline Total & 24 & 100 \\
\hline
\end{tabular}

Tabel 1 mendeskripsikan umur dari responden yang berjumlah 24 orang. Kelompok umur 3035 tahun berjumlah 6 orang atau 25\%, kelompok umur 36-40 berjumlah 17 orang atau $70.8 \%$, dan kelompok umur $>40$ tahun berjumlah 1 orang atau $4.2 \%$. Hasil dari tabel tersebut menjelaskan penggunaan karyawan dalam masa produktif, di PT. Perkebunan Nusantara III umur produktif karyawan di kebun yaitu 18-55 tahun.

2. Responden berdasarkan status

Tabel 2. Karakteristik responden berdasarkan status

\begin{tabular}{ccc}
\hline Status & Jumlah (orang) & Persentase (\%) \\
\hline Menikah & 23 & 95.8 \\
Belum menikah & 1 & 4.2 \\
\hline Total & 24 & 100
\end{tabular}


Tabel 2 memberikan gambaran mengenai status dari karyawan pemanen di Afdeling 3. Sebagian besar karyawan pemanen berstatus sudah menikah yang berjumlah 23 orang atau $95.8 \%$, sedangkan karyawan yang belum menikah berjumlah 1 orang atau $4.2 \%$. Status juga termasuk dalam penentuan kompensasi yang diterima. Dilihat dari PKB PTPN III bahwa ada beberapa tunjangan yang diberikan tergantung jumlah keluarga seperti pada pasal 32 mengenai tunjangan beras, setiap karyawan diberikan $15 \mathrm{~kg}$, istri/suami yang tidak bekerja diberikan $9 \mathrm{~kg}$, tiap anak (maksimal 3 orang) diberikan $7.5 \mathrm{~kg}$.

3. Responden berdasarkan golongan

Tabel 3. Karakteristik responden berdasarkan golongan

\begin{tabular}{ccc}
\hline Golongan & Jumlah (orang) & Persentase $(\boldsymbol{\%})$ \\
\hline $1 \mathrm{a} / 10$ & 2 & 8.3 \\
$1 \mathrm{a} / 11$ & 3 & 12.5 \\
$1 \mathrm{a} / 12$ & 3 & 12.5 \\
$1 \mathrm{a} / 13$ & 2 & 8.3 \\
$1 \mathrm{a} / 14$ & 1 & 4.2 \\
$1 \mathrm{a} / 4$ & 1 & 4.2 \\
$1 \mathrm{a} / 5$ & 3 & 12.5 \\
$1 \mathrm{a} / 6$ & 3 & 12.5 \\
$1 \mathrm{a} / 8$ & 3 & 12.5 \\
$1 \mathrm{a} / 9$ & 3 & 12.5 \\
\hline Total & 24 & 100.0 \\
\hline
\end{tabular}

Golongan karyawan pemanen di kebun Sei Silau Afdeling 3 yaitu 1a dengan tingkatan 0-14. Tingkatan golongan akan mempengaruhi jumlah gaji dan tunjangan yang diterima oleh karyawan serta menjadi acuan untuk kenaikan jabatan. Golongan dari karyawan dapat turun apabila karyawan tersebut tidak memenuhi syarat lagi untuk menduduki posisi tersebut. Golongan dalam perusahaan PTPN III terdapat 16 golongan yaitu IA (0-14), IB (0-13), IC (0-12), ID (0-11), IIA (0-10), IIB (09), IIC (0-7), IID (0-6), IIIA (0-11), IIIB (0-10), IIIC (0-7), IIID (0-11), IVA (0-10), IVB (0-6), IVC (0-9), dan IVD (0-6). Golongan karyawan pemanen yaitu IA sampai ID. Golongan Mandor yaitu IIA-IID. Golongan staff yaitu IIIA-IVD, posisi staff yaitu Asisten Afdeling hingga Manajer.

4. Responden berdasarkan pendidikan

Tabel 4. Karakteristik responden berdasarkan pendidikan

\begin{tabular}{ccc}
\hline Tingkat Pendidikan & Jumlah (orang) & Persentase (\%) \\
\hline SD & 1 & 4.2 \\
SMP & 12 & 50.0 \\
SMA & 10 & 41.6 \\
D-3 & 1 & 4.2 \\
\hline Total & 24 & 100 \\
\hline
\end{tabular}

Hasil olahan data pada tabel 4 menunjukkan bahwa karyawan pemanen di Afdeling 3 dengan pendidikan terakhir SD sebanyak 1 orang atau 4.2\%, SMP 12 orang atau 50.0\%, SMA 10 orang atau 41.6\%, dan D-3 1 orang atau 4.2\%. Mayoritas pendidikan karyawan di Afdeling 3 berpendidikan SMP. Berdasarkan Perjanjian Kerja Bersama-Direksi PTPN-III dengan SPBUN-PTPN-III bahwasanya persyaratan tenaga kerja yang diterima sebagai karyawan pelaksana di bagian kebun/unit harus berpendidikan serendah-rendahnya berijazah SD/sederajat.

5. Karakteristik responden berdasarkan masa kerja

Tabel 5. Karakteristik responden berdasarkan masa kerja

\begin{tabular}{ccc}
\hline Masa Kerja (tahun) & Jumlah (orang) & Persentase (\%) \\
\hline $1-5$ & 5 & 20.8 \\
$6-10$ & 14 & 58.4 \\
$>10$ & 5 & 20.8 \\
\hline Total & 24 & 100 \\
\hline
\end{tabular}


Karakteristik karyawan di Afdeling 3 kebun Sei Silau dari 30 orang pemanen berdasarkan masa kerja dikelompokkan dalam 3 bagian, 1-5 tahun berjumlah 5 orang atau 20.8\%, 6-10 tahun berjumlah 14 orang atau $58.4 \%$, dan $>10$ tahun berjumlah 5 orang atau $20.8 \%$. Mayoritas karyawan pemanen di Afdeling 3 kebun Sei Silau telah bekerja selama 6-10 tahun. Hal ini menjelaskan bahwasanya karyawan pemanen telah cukup menguasai dan memahami pekerjaan atau tugastugasnya.

\section{Deskripsi Kategori Variabel}

1. Kompensasi

Hasil analisis deskriptif untuk variabel kompensasi diperoleh nilai minimum sebesar 16, nilai maksimum sebesar 32, mean sebesar 26.96, dan standar deviasi sebesar 3.77. Selanjutnya data kompensasi dikategorikan dengan menggunakan nilai rata-rata (mean) dan simpangan baku (SD). Jumlah item pertanyaan untuk variabel kompensasi terdiri dari 8 pertanyaan yang masing-masing mempunyai skor 1, 2, 3, 4, dan 5. Kategori variabel kompensasi dapat dilihat pada tabel 6 .

Tabel 6. Kategorisasi variabel kompensasi

\begin{tabular}{lccc}
\hline \multicolumn{1}{c}{ Kategori } & Interval Skor & Jumlah & Persentase (\%) \\
\hline Tinggi & $\mathrm{X} \geq 30.73$ & 4 & 16.7 \\
Sedang & $23.19 \leq \mathrm{X}<30.73$ & 17 & 70.8 \\
Rendah & $\mathrm{X}<23.19$ & 3 & 12.5 \\
\hline Jumlah & & 24 & 100 \\
\hline
\end{tabular}

Hasil dari analisis kategorisasi yang tertera pada tabel 6 menunjukkan penilaian terhadap variabel kompensasi dalam kategori "tinggi" sebanyak 16.7\%, artinya 16.7\% karyawan pemanen Afdeling 3 merasa kompensasi yang diterima sudah "sangat sesuai" dengan apa yang sudah diberikan untuk perusahaan. Responden yang memberikan penilaian terhadap variabel kompensasi dalam kategori "sedang" sebanyak 70.8\%. Artinya, 70.8\% karyawan pemanen Afdeling 3 merasa kompensasi yang diterima "sudah sesuai" dengan apa yang diberikan kepada perusahaan. Responden yang memberikan penilaian terhadap variabel kompensasi dalam kategori "rendah" sebanyak $12.5 \%$. Artinya $12.5 \%$ karyawan pemanen di Afdeling 3 merasa kompensasi yang diberikan perusahaan "belum sesuai" dengan apa yang sudah dikerjakannya terhadap perusahaan. Sebagian besar dari karyawan pemanen di Afdeling 3 merasa kompensasi yang diterima sudah sesuai dengan apa yang diberikan terhadap perusahaan, namun belum dirasakan maksimal oleh karyawan.

\section{Motivasi kerja}

Hasil analisis deskriptif untuk variabel motivasi kerja diperoleh nilai minimum sebesar 29, nilai maksimum sebesar 43, mean sebesar 34.63, dan standar deviasi sebesar 3.308. Selanjutnya data motivasi kerja dikategorikan dengan menggunakan nilai rata-rata (mean) dan simpangan baku (SD). Jumlah item pertanyaan untuk variabel motivasi kerja terdiri dari 9 pertanyaan yang masing-masing mempunyai skor 1, 2, 3, 4, dan 5. Kategori variabel motivasi kerja dapat dilihat pada tabel 7.

Tabel 7. Kategorisasi variabel motivasi kerja

\begin{tabular}{lccc}
\hline \multicolumn{1}{c}{ Kategori } & Interval Skor & Jumlah & Persentase (\%) \\
\hline Tinggi & $\mathrm{X} \geq 37.938$ & 2 & 8.3 \\
Sedang & $31.322 \leq \mathrm{X}<37.938$ & 18 & 75 \\
Rendah & $\mathrm{X}<31.322$ & 4 & 16.7 \\
\hline Jumlah & & 24 & 100 \\
\hline
\end{tabular}

Hasil uji kategorisasi pada tabel 7 mengenai variabel motivasi menunjukkan responden yang memberikan penilaian yang termasuk dalam kategori "tinggi" berjumlah $8.3 \%$, artinya $8.3 \%$ karyawan pemanen di Afdeling 3 kebun Sei Silau memiliki motivasi yang "tinggi" untuk melaksanakan pekerjaannya. Responden yang memberikan penilaian terhadap variabel motivasi kerja dalam kategori "sedang" berjumlah 75\%, artinya 75\% karyawan pemanen di Afdeling 3 kebun Sei Silau memiliki motivasi yang "sedang" dalam dirinya untuk melaksanakan pekerjaannya. Responden yang memberikan penilaian terhadap variabel motivasi dalam kategori "rendah" 
berjumlah $16.7 \%$, artinya $16.7 \%$ karyawan pemanen di Afdeling 3 kebun Sei Silau "kurang" memiliki motivasi dalam dirinya untuk melaksanakan pekerjaannya. Kesimpulannya mayoritas dari karyawan pemanen di Afdeling 3 kebun Sei Silau memiliki motivasi yang "sedang" dalam dirinya untuk melaksanakan pekerjaannya, oleh karena itu diperlukan upaya untuk meningkatkan motivasi kerja karyawan pemanen tersebut.

\section{Kinerja karyawan}

Hasil analisis deskriptif untuk variabel kinerja diperoleh nilai minimum sebesar 28, nilai maksimum sebesar 46, mean sebesar 38, dan standar deviasi sebesar 4.253. Selanjutnya data kinerja dikategorikan dengan menggunakan nilai rata-rata (mean) dan simpangan baku (SD). Jumlah item pertanyaan untuk variabel kinerja terdiri dari 10 pertanyaan yang masing-masing mempunyai skor 1 , 2, 3, 4, dan 5. Kategori variabel kinerja dapat dilihat pada Tabel 8.

Tabel 8. Kategorisasi variabel kinerja

\begin{tabular}{lccc}
\hline \multicolumn{1}{c}{ Kategori } & Interval Skor & Jumlah & Persentase (\%) \\
\hline Tinggi & $\mathrm{X} \geq 42.253$ & 6 & 25 \\
Sedang & $33.747 \leq \mathrm{X}<42.253$ & 17 & 70.8 \\
Rendah & $\mathrm{X}<33.747$ & 1 & 4.2 \\
\hline Jumlah & & 24 & 100 \\
\hline
\end{tabular}

Hasil olahan data pada tabel 8 menunjukkan penilaian karyawan pemanen Afdeling 3 kebun Sei Silau yang dilakukan oleh Mandor panen. Penilaian tersebut dikelompokkan dalam 3 kategori. Penilaian variabel kinerja yang termasuk dalam kategori "tinggi" berjumlah $25 \%$, artinya $25 \%$ karyawan pemanen di Afdeling 3 kebun Sei Silau telah memprioritaskan pekerjaan dan tujuan organisasi sehingga melaksanakan pekerjaan secara baik untuk perusahaan. Penilaian variabel kinerja yang termasuk dalam kategori "sedang" berjumlah $70.8 \%$, artinya $70.8 \%$ dari karyawan pemanen Afdeling 3 kebun Sei Silau "mampu" memprioritaskan pekerjaan dan tujuan organisasi, namun belum maksimal. Penilaian kinerja yang termasuk kategori "rendah" berjumlah $4.2 \%$, artinya 4.2\% karyawan pemanen di Afdeling 3 kebun Sei Silau "kurang" memprioritaskan pekerjaan dan tujuan perusahaan, sehingga kualitas kerja menjadi rendah.

\section{Analisis Data}

1. Uji Reliabilitas dan uji validitas

a. Uji Reliabilitas

Uji reliabilitas merupakan pengujian keakuratan dan ketepatan dari suatu alat ukur dalam suatu prosedur pengukuran agar hasil suatu pengukuran dapat dipercaya. Hasil pengukuran dapat dipercaya apabila pengukuran dilakukan berulang-ulang terhadap kelompok yang sama dan hasil pengukurannya relatif sama. Pengujian reliabilitas dalam penelitian ini menggunakan formula cronbach aplha. Ketentuan standar perbandingan nilai Alpha dapat dilihat sebagai berikut: (Ghozali, 2013)

a. Nilai Cronbach Alpha 0.00-0.20, berarti kurang reliabel

b. Nilai Cronbach Alpha 0.21-0.40, berarti agak reliabel

c. Nilai Cronbach Alpha 0.41-0.60, berarti cukup reliabel

d. Nilai Cronbach Alpha 0.61-0.80, berarti reliabel

e. Nilai Cronbach Alpha 0.81-1.00, berarti sangat reliabel Tabel 9.

Hasil uji reliabilitas terhadap variabel kompensasi, motivasi dan kinerja dapat dilihat pada

Tabel 9. Hasil uji reliabilitas

\begin{tabular}{lcl}
\hline \multicolumn{1}{c}{ Variabel } & Cronbach Alpha & Keterangan \\
\hline Kompensasi (X1) & 0.777 & Reliabel \\
Motivasi kerja (X2) & 0.711 & Reliabel \\
Kinerja (Y) & 0.621 & Reliabel \\
\hline
\end{tabular}


Data olahan melalui software SPSS v.20 mengenai uji reliabilitas variabel penelitian dapat dilihat pada tabel 9, dari tabel tersebut dapat diketahui bahwa cronbach's alpha untuk keseluruhan butir pertanyaan variabel kompensasi (X1) reliabel. Cronbach's alpha untuk keseluruhan pertanyaan variabel motivasi kerja (X2) reliabel, dan cronbach's alpha untuk keseluruhan pertanyaan variabel kinerja (Y) reliabel. Artinya alat ukur yang digunakan untuk dalam penelitian ini dapat dipercaya atau diandalkan.

\section{b. Uji validitas}

Uji validitas merupakan pengujian yang digunakan untuk mengetahui sejauh mana alat ukur yang digunakan dalam mengukur apa yang diukur. Alat ukur yang digunakan dalam penelitian ini yaitu kuesioner, uji validitas berguna untuk mengukur sah atau valid tidaknya suatu kuesioner. Suatu kuesioner dikatakan valid jika pertanyaan pada kuesioner mampu untuk mengungkapkan sesuatu yang akan diukur oleh kuesioner tersebut. Uji validitas dapat menggunakan software SPSS v.20 dengan membandingkan nilai korelasi Product momen dengan nilai r-tabel menggunakan tingkat keyakinan 95\% $(\alpha=5 \%)$ ataupun menggunakan program Microsoft Excel. Nilai r-tabel dengan jumlah sampel 24 menggunakan uji 2 arah (n [jumlah sampel]-k [jumlah variabel bebas]-1), maka didapatkan nilai r-tabel yaitu 0.4132. Hasil uji validitas dapat dilihat pada Tabel 10.

Tabel 10. Hasil uji validitas

\begin{tabular}{lccc}
\hline \multicolumn{1}{c}{ Variabel } & R-hitung & R-tabel & Keterangan \\
\hline Kompensasi (X1) & $0.4225-0.6569$ & 0.4132 & Valid \\
Motivasi Kerja (X2) & $0.4152-0.7896$ & 0.4132 & Valid \\
Kinerja (Y) & $0.4166-0.6240$ & 0.4132 & Valid \\
\hline
\end{tabular}

Tabel 10 menunjukkan hasil uji validitas terhadap variabel yang digunakan dalam penelitian ini secara keseluruhan dinyatakan valid. Hal ini dapat dilihat dari nilai $r$-hitung mempunyai nilai yang lebih besar dibandingkan dengan r-tabel. Hasil dari uji validitas ini dapat diartikan bahwa semua indikator yang digunakan dalam penelitian ini dinyatakan valid. Artinya alat ukur yang digunakan dalam penelitian ini memberikan hasil yang relatif konsisten apabila dilakukan pengukuran diulangi untuk kedua kali atau lebih.

2. Uji asumsi klasik

Pengujian asumsi klasik digunakan untuk memberikan kepastian bahwa persamaan regresi yang didapatkan memiliki ketepatan dalam estimasi, tidak bias, dan konsisten. Uji ini merupakan uji prasyarat melakukan uji regresi agar memenuhi kriteria BLUE (Best, Linear, Unbiased, and Estimated). Uji asumsi klasik dilakukan uji normalitas, uji linearitas, uji multikolinearitas dan uji heteroskedastisitas sebagai berikut: (Mardani, 2017).

\section{a. Uji normalitas}

Uji normalitas merupakan pengujian yang dilakukan dengan tujuan untuk menilai sebaran data pada kelompok data atau variabel, apakah berkontribusi normal atau tidak. Pengujian ini dilakukan karena jumlah sampel kecil dari 30, biasanya sampel yang melebihi 30 dapat diasumsikan berkontribusi normal. Uji normalitas dilakukan dengan software SPSS v.20. Hasil pengujian dapat dilihat pada tabel 11 .

Tabel 11. Hasil uji normalitas

\begin{tabular}{lcc}
\hline \multicolumn{1}{c}{ Variabel } & Signifikan & Keterangan \\
\hline Kompensasi & 0.518 & Normal \\
Motivasi kerja & 0.087 & Normal \\
Kinerja karyawan & 0.741 & Normal \\
\hline
\end{tabular}

Hasil uji normalitas dari data variabel yang digunakan dalam penelitian memiliki nilai signifikan lebih besar dari 0.05 (sig>0.05), sehingga dapat dinyatakan bahwa data penelitian berdistribusi normal. Artinya sebaran data penelitian yang digunakan berdistribusi normal. 
b. Uji linearitas

Uji linearitas bertujuan untuk mengetahui apakah dua variabel mempunyai hubungan yang linear atau tidak secara signifikan. Uji dilakukan menggunakan software SPSS v.20 dengan taraf signifikasi 0.05 . Dua variabel dapat dinyatakan mempunyai hubung linear apabila nilai signifikansi (Linearity) kecil dari 0.05. Hasil uji linearitas dapat dilihat pada Tabel 12.

Tabel 12. Hasil uji linearitas

\begin{tabular}{lcc}
\hline \multicolumn{1}{c}{ Variabel } & Signifikan (Linearity) & Keterangan \\
\hline Kompensasi & 0.000 & Linear \\
Motivasi kerja & 0.004 & Linear \\
\hline
\end{tabular}

Tabel 12 menunjukkan bahwa semua variabel memiliki nilai signifikansi (Linearity) lebih kecil dari 0.05 . Hal ini membuktikan semua variabel yang digunakan dalam penelitian ini adalah linear. Artinya penelitian ini mempunyai hubungan yang linear atau searah.

\section{c. Uji multikolineritas}

Uji multikolinearitas adalah uji yang dilakukan untuk memastikan apakah di dalam sebuah model regresi ada interkorelasi atau kolinearitas antar variabel bebas. Indikator uji multikolinearitas yaitu apabila nilai toleransi diatas 0.1 dan nilai VIF di bawah 10 , maka tidak terjadi multikolinearitas. Pengujian dilakukan dengan menggunakan software SPSS v.20 yang dapat dilihat hasilnya pada Tabel 13.

Tabel 13. Hasil uji multikolinearitas

\begin{tabular}{lccc}
\hline \multicolumn{1}{c}{ Variabel } & Tolerance & VIF & Keterangan \\
\hline Kompensasi & 0.773 & 1.294 & Tidak terjadi multikolinearitas \\
Motivasi kerja & 0.773 & 1.294 & Tidak terjadi multikolinearitas \\
\hline
\end{tabular}

Tabel 13 menunjukkan bahwa semua variabel mempunyai nilai toleransi di atas 0.1 dan nilai VIF di bawah 10, sehingga dapat dinyatakan bahwa model regresi dalam penelitian ini tidak terjadi multikolinearitas. Artinya dalam penelitian ini variabel kompensasi dan motivasi kerja tidak terjadi multikolinearitas. Variabel kompensasi dan motivasi kerja dalam penelitian ini berdiri sendiri atau tidak saling terkait satu sama lain, sehingga model regresi dalam penelitian ini memenuhi syarat untuk dilaksanakan analisis.

\section{d. Uji heteroskedastisitas}

Uji heteroskedastisitas merupakan uji untuk menilai apakah ada ketidaksamaan varian dari residual untuk semua pengamatan pada model regresi linear. Apabila asumsi heteroskedastisitas tidak terpenuhi, maka model regresi dinyatakan tidak valid dijadikan sebagai alat peramalan. Pengujian dilakukan dengan menggunakan software SPSS v.20 dengan indikator pola pada scatter plot, apabila titik-titik pada scatter plot membentuk pola tertentu seperti bergelombang atau mengumpul pada satu titik maka dinyatakan terjadi heteroskedastisitas. Pola yang diharapkan yaitu titik-titik menyebar dari atas sampai bawah dari sumbu Y. Hasil uji heteroskedastisitas dapat dilihat pada Gambar 2.

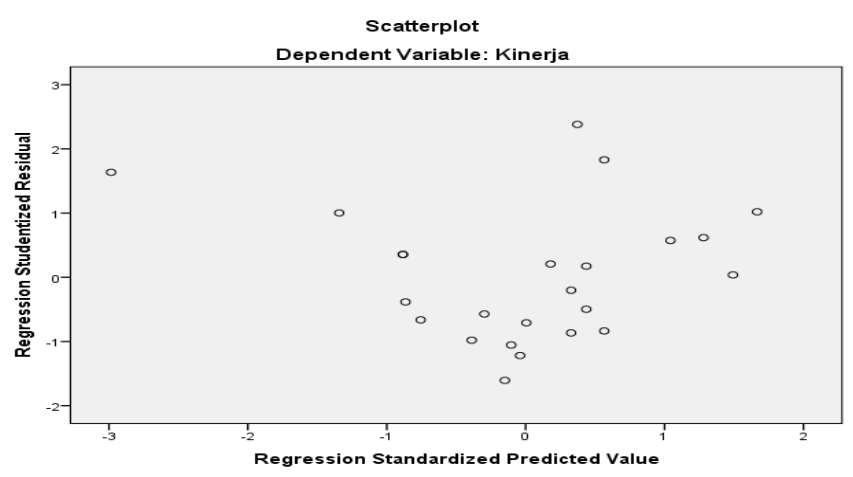

Gambar 1. Scatterplot heteroskedastisitas 
Hasil uji heteroskedastisitas pada gambar 1 menunjukkan titik-titik pada scatter plot menyebar dari atas hingga bawah sumbu Y. Hal ini membuktikan bahwa tidak terjadi heteroskedastisitas. Jadi, model dalam penelitian ini dapat dinyatakan memenuhi syarat analisis yang bersifat homokedastisitas.

\section{Uji hipotesis}

Uji hipotesis merupakan metode untuk pengambilan keputusan yang didasarkan pada analisis data, baik dari percobaan yang terkontrol, maupun dari observasi atau yang tidak terkontrol. Hipotesis dalam penelitian ini mengenai variabel kompensasi dan motivasi kerja terhadap kinerja karyawan. Analisis regresi berganda dipilih untuk menganalisis hipotesis dalam penelitian ini, analisis menggunakan software SPSS v.20. Hasil analisis regresi berganda dapat dilihat pada Tabel14.

Tabel 14. Hasil uji regresi berganda

\begin{tabular}{lccc}
\hline \multicolumn{1}{c}{ Variabel Independen } & Koefisien & T-hitung & Signifikan \\
\hline Konstanta & 3.438 & 0.985 & 0.336 \\
Kompensasi & 0.951 & 9.596 & 0.000 \\
Motivasi kerja & 0.257 & 2.318 & 0.031 \\
$\mathrm{R}$ & 0.938 & & \\
R Square $\left(\mathrm{R}^{2}\right)$ & 0.88 & & \\
Adjusted R Square & 0.868 & & 0.000 \\
F-hitung & 76.775 & & \\
F-tabel & 3.47 & & \\
T-tabel & 2.080 & & \\
$\alpha$ (taraf nyata) & 0.05 & & \\
\hline
\end{tabular}

Persamaan regresi berganda yang diperoleh berdasarkan data hasil uji regresi berganda pada tabel 14 dapat dilihat sebagai berikut:

$$
\begin{aligned}
& Y=a+b_{1} X_{1}+b_{2} X_{2} \\
& Y=3.438+0.951 X_{1}+0.257 X_{2}
\end{aligned}
$$

Persamaan tersebut dapat diinterprestasikan sebagai berikut:

a. Nilai konstanta dari hasil uji regresi berganda yaitu 3.438. Artinya terjadi hubungan positif variabel independen (kompensasi dan motivasi kerja) terhadap kinerja karyawan pemanen di Afdeling 3 kebun Sei Silau. Apabila variabel kompensasi dan motivasi kerja naik, maka akan terjadi kenaikan kinerja dan sebaliknya.

b. Nilai koefisien dari variabel kompensasi yaitu 0.951. Artinya apabila terjadi perubahan positif (penambahan) pada variabel kompensasi sebesar satu satuan, maka akan terjadi penambahan nilai kinerja sebesar 0.951 per satu satuan dan sebaliknya. Hal ini berlaku dengan asumsi nilai parameter kompensasi mempunyai nilai yang konstan.

c. Nilai koefisien dari variabel motivasi kerja yaitu 0.257. Artinya apabila terjadi perubahan positif (penambahan) pada variabel motivasi kerja sebesar satu satuan, maka akan terjadi penambahan nilai kinerja sebesar 0.257 per satu satuan dan sebaliknya. Hal ini berlaku dengan asumsi nilai parameter motivasi kerja mempunyai nilai yang konstan.

Selain nilai koefisien dan konstanta, tabel 14 juga menunjukkan nilai $\mathrm{R}$ sebesar 0.938 , dengan demikian didapatkan nilai koefisien determinasi (R2) sebesar 0.88. Hal ini berarti bahwa variabel independen (kompensasi dan motivasi) mempengaruhi variabel terikat (kinerja karyawan pemanen di Afdeling 3 kebun Sei Silau) secara bersama-sama sebesar 88\%. Sisanya 12\% dipengaruhi oleh faktor-faktor lain yang tidak termasuk dalam penelitian ini seperti umur, masa kerja, kesehatan, dan faktor lainnya. Nilai Adjusted R Square yaitu 0.868, interprestasinya sama dengan nilai koefisien determinasi yaitu variabel independen (kompensasi dan motivasi) mempengaruhi variabel terikat (kinerja karyawan pemanen di Afdeling 3 kebun Sei Silau) secara bersama-sama sebesar 86.8\%, sisanya $13.2 \%$ dipengaruhi oleh faktor-faktor lain yang tidak termasuk dalam penelitian ini.

Penggunaan R2 sering menimbulkan permasalahan. Nilai R2 akan selalu meningkat dengan adanya penambahan variabel bebas dalam suatu model, walaupun variabel tersebut mempengaruhi 
variabel terikatnya. Disarankan untuk menggunakan nilai Adjusted R Square, nilainya dapat naik atau turun dengan penambahan variabel baru (Konsultan statistik, 2011).

\section{Uji F}

Uji F disebut juga dengan uji serempak atau uji Anova, yaitu uji yang digunakan untuk melihat bagaimana pengaruh semua variabel independen (bebas) secara bersama-sama terhadap variabel dependennya (terikat). Variabel independen yang digunakan dalam penelitian ini yaitu kompensasi (X1) dan motivasi kerja (X2), sedangkan variabel dependennya yaitu kinerja karyawan (Y). Hasil uji $\mathrm{F}$ yang dilakukan dapat dilihat pada tabel 14 dengan nilai F-hitung sebesar 76.775. Jika dibandingkan dengan nilai F-tabel, maka nilai F-hitung lebih besar dari F-tabel $(76.775>$ F-tabel $=$ 3.47). Nilai signifikan dari uji $F$ sebesar 0.000 , nilainya lebih kecil dibandingkan dengan nilai taraf nyata $(0.000<\alpha=0.05)$. Artinya variabel kompensasi (X1) dan motivasi kerja (X2) secara bersamasama berpengaruh positif atau signifikan terhadap kinerja (Y) karyawan pemanen di Afedling 3 kebun Sei Silau, dengan demikian hipotesis pertama (H1c) diterima dan hipotesis nol (H0c) ditolak.

\section{Ujit}

Uji t disebut juga dengan uji parsial, yaitu uji yang digunakan untuk melihat bagaimana pengaruh masing-masing variabel independen (bebas) terhadap variabel dependennya (terikat). Uji $\mathrm{t}$ dilakukan dengan membandingkan nilai t-hitung dengan nilai t-tabel, atau dengan cara membandingkan nilai signifikannya dengan nilai taraf nyata $(\alpha)$. Hasil uji t-hitung dapat dilihat pada Tabel 14.

a. Variabel kompensasi $\left(\mathrm{X}_{1}\right)$

Nilai t-hitung untuk variabel kompensasi (X1) yang didapatkan dari uji yang dilakukan yaitu sebesar 9.596, nilai ini lebih besar dibandingkan dengan nilai t-tabel $(9.596>t$-tabel $=2.080)$, dan nilai signifikan dari variabel kompensasi yaitu sebesar 0.000 , lebih kecil dari nilai taraf nyata $(0.000$ $<\alpha=0.05$ ). artinya pemberian kompensasi berupa tingkatan gaji, bonus, tunjangan, jaminan sosial, dan fasilitas karyawan berpengaruh signifikan terhadap kinerja karyawan pemanen Afdeling 3 kebun Sei Silau. Jadi hipotesis pertama (H1a) diterima dan hipotesis nol (H0a) ditolak.

b. Variabel motivasi kerja $\left(\mathrm{X}_{2}\right)$

Nilai t-hitung untuk variabel motivasi kerja (X2) yang didapatkan dari uji yang dilakukan yaitu sebesar 2.318, nilai ini lebih besar dibandingkan dengan nilai t-tabel $(2.318>\mathrm{t}$-tabel $=2.080)$, dan nilai signifikansi dari variabel motivasi kerja yaitu sebesar 0.031 , lebih kecil dari nilai taraf nyata $(0.031<\alpha=0.05)$. artinya pemberian motivasi kerja berupa kesesuaian gaji, hubungan kerja, kebijakan perusahaan, kesempatan yang diberikan perusahaan, dan lingkungan kerja berpengaruh signifikan terhadap kinerja karyawan pemanen di Afdeling 3 kebun Sei Silau. Jadi hipotesis pertama (H1b) diterima dan hipotesis nol (H0b) ditolak.

Hasil dari uji t yang dilakukan menunjukkan bahwa variabel yang paling dominan berpengaruh terhadap kinerja karyawan adalah variabel kompensasi (X1). Hal ini dapat dilihat dari nilai t-hitung variabel kompensasi yang paling besar dibandingkan dengan variabel motivasi kerja yaitu $9.596>$ 2.318 dan nilai signifikansi kompensasi lebih kecil dari nilai signifikansi motivasi kerja yaitu 0.000 $<0.031$.

\section{KESIMPULAN}

Penelitian ini dapat disimpulkan kompensasi dan motivasi kerja secara bersama-sama berpengaruh positif atau signifikan terhadap kinerja karyawan pemanen di Afdeling 3 kebun Sei Silau sebesar $86.8 \%$. Semakin tinggi kompensasi dan motivasi kerja yang diberikan kepada perusahaan, maka kinerja karyawan akan meningkat dan sebaliknya. Kompensasi dan motivasi kerja secara masing-masing berpengaruh positif atau signifikan terhadap kinerja karyawan pemanen di Afdeling 3 kebun Sei Silau. Kompensasi lebih berpengaruh dominan pada model dibandingkan motivasi kerja yang terlihat pada nilai signifikansi yang lebih kecil. 


\section{DAFTAR PUSTAKA}

Ghozali, I. 2013. Aplikasi analisis multivariat dengan program SPSS. Badan penerbit universitas diponegoro. Diponegoro. 432 hal

Hasibuan dan Malayu, 2014. Manajemen sumber daya manusia. Edisi revisi. Bumi aksara. Yogyakarta. 288 hal.

Konsultan statistik. 2011. Koefisien determinasi pada regresi linear. Artikel. www.konsultanstatistik.com.

Mardani, R. 2017. Teori asumsi klasik regresi linear berganda. Artikel. http://mardanijournal.wordpress.com.

Sinungan, 2002. Produktivitas. Bumi aksara. Yogyakarta. 166 hal 